\title{
Innovating SMEs and regions : the need for policy intelligence and interactive policies
}

Citation for published version (APA):

Nauwelaers, C. C. E. M. G., \& Wintjes, R. J. M. (2002). Innovating SMEs and regions : the need for policy intelligence and interactive policies. Technology Analysis \& Strategic Management, 14((2)), 201-215. https://doi.org/10.1080/09537320220133866

Document status and date:

Published: 01/01/2002

DOI:

10.1080/09537320220133866

Document Version:

Publisher's PDF, also known as Version of record

\section{Please check the document version of this publication:}

- A submitted manuscript is the version of the article upon submission and before peer-review. There can be important differences between the submitted version and the official published version of record.

People interested in the research are advised to contact the author for the final version of the publication, or visit the DOI to the publisher's website.

- The final author version and the galley proof are versions of the publication after peer review.

- The final published version features the final layout of the paper including the volume, issue and page numbers.

Link to publication

\footnotetext{
General rights rights.

- You may freely distribute the URL identifying the publication in the public portal. please follow below link for the End User Agreement:

www.umlib.nl/taverne-license

Take down policy

If you believe that this document breaches copyright please contact us at:

repository@maastrichtuniversity.nl

providing details and we will investigate your claim.
}

Copyright and moral rights for the publications made accessible in the public portal are retained by the authors and/or other copyright owners and it is a condition of accessing publications that users recognise and abide by the legal requirements associated with these

- Users may download and print one copy of any publication from the public portal for the purpose of private study or research.

- You may not further distribute the material or use it for any profit-making activity or commercial gain

If the publication is distributed under the terms of Article $25 \mathrm{fa}$ of the Dutch Copyright Act, indicated by the "Taverne" license above, 


\title{
Innovating SMEs and Regions: The Need for Policy Intelligence and Interactive Policies
}

\section{GLAIRE NAUWELAERS \& RENÉ WINTJES}

\begin{abstract}
Based on the empirical findings achieved through comparative research involving 40 innovation policy instruments from 11 European regions, this paper proposes a shift in rationale and in the broad orientations of innovation policy to focus on addressing SMEs in their regional context. The main role for innovation policy, which aims to increase the capacity of a region and the capabilities of its SMEs to innovate, is to foster interactive learning within the firms and within the region. This calls for an interactive mode of policy intervention. The paper deals also with the question of how to build a coherent portfolio of policy instruments, taking into account both regional situations and specific SMEs needs in terms of innovation. The key message is that there is no 'one-size-fits-all' policy portfolio. Regional differences in innovation capabilities call for a tailored mix of policy instruments. One salient element of the conclusion is the need for more 'policy intelligence' in this complex field.
\end{abstract}

\section{Introduction}

Today, at national, European and regional levels, innovation ranks high on policy agendas. This evolution is nurtured by the understanding that innovation is the key to economic development for advanced, high-wage countries. It is becoming visible through a gradual shift in policy statements from support for R\&D and technology diffusion to the promotion of innovation. The understanding of innovation as something different from $\mathrm{R} \& \mathrm{D}$ and the diffusion of technology is gaining ground: innovation refers to a behaviour of enterprises, planning and implementing changes in their practices, in order to come up with new products, processes, services or organization. This change in focus reflects efforts based on the view that innovation is an interactive as opposed to a linear process. ${ }^{1}$ As such, traditional S\&T policies do not offer the unique response needed to support innovative practices. Instead, many other elements in addition to science and technology play a role in innovation and need to be tackled by innovation policy. ${ }^{2}$ When envisaged within this enlarged framework, innovation policies are still in their infancy.

The SMEPOL project, carried out under the 'Targeted Socio-Economic Research' programme of the European Union, is a collaborative project of seven academic research groups $^{3}$ that addresses the question of the efficiency conditions for innovation policy, based on a comparative analysis of innovation policy instruments. The research targets instruments specifically developed for SMEs, implemented at the regional level. As shown in Figure 1, the analysis covers six key questions: 


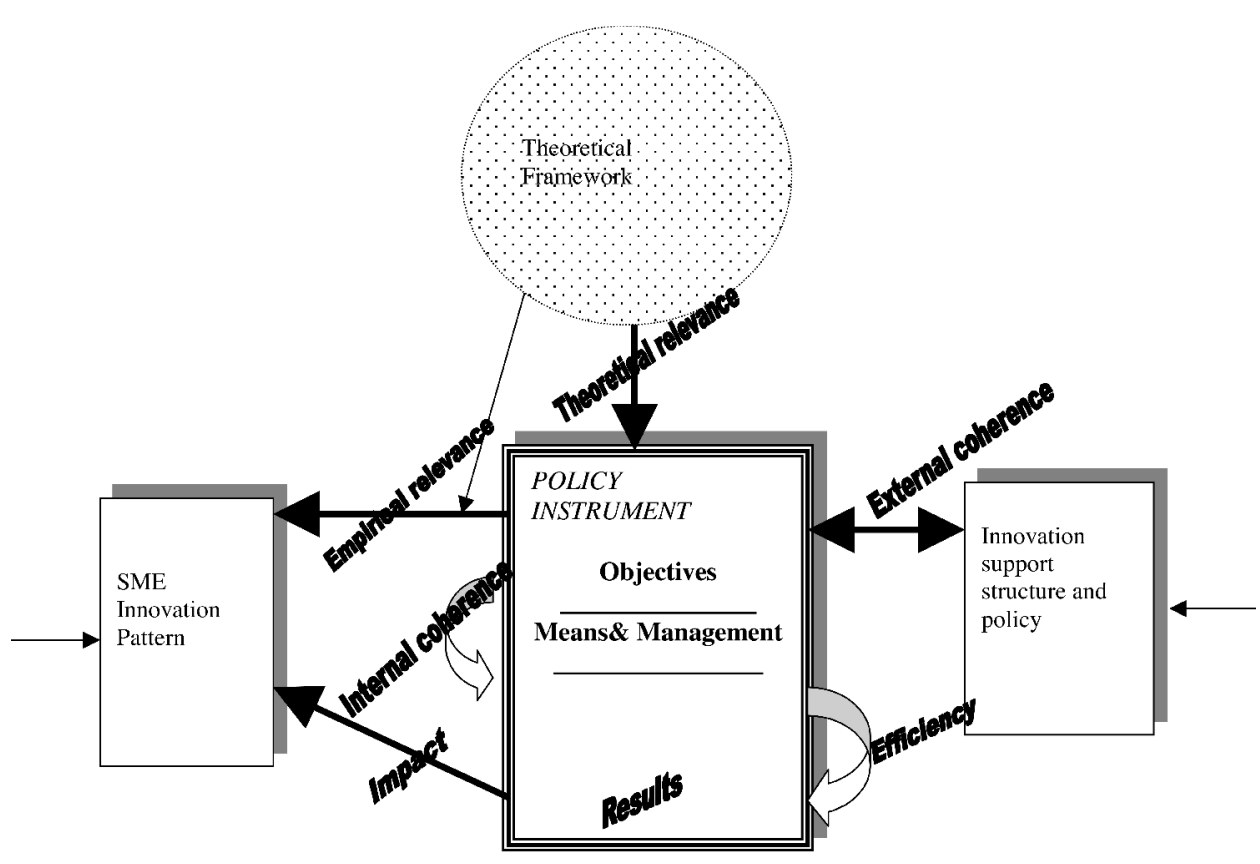

Figure 1. Framework of analysis for the SMEPOL project

(1) What is the relevance of the policy instruments according to lessons from theory?

(2) Do these instruments tackle real innovation needs from companies?

(3) Do the means correspond to aims of the policy instruments?

(4) What is the efficiency of the instruments (cost-benefit ratio)?

(5) What are the results achieved by these instruments and what are their impacts?

(6) How are the instruments co-ordinated with the rest of the policy system?

These questions have been dealt with in 11 regional environments, ${ }^{4}$ and for 40 policy instruments of various sorts, including direct subsidies to firms (for R\&D projects or personnel), technological centres, mobility schemes for researchers, innovation brokers and cluster policies.

The thesis at the core of the study is that the variety of regional contexts, the diversity of firms' abilities and attitudes, and the driving forces and barriers towards innovation, prevent the search for one permanent 'best practice' policy, valid for each and every situation. This is not to say, however, that nothing general can be concluded in response to the question of how to improve the efficiency of policy instruments to support innovation in SMEs. Rather, the results from the analyses of a variety of innovation policy tools, based on the same conceptual background, provide an answer to this crucial question. The various tools form a rich scope of opportunities for better practice regarding the policy process of addressing innovation of SMEs in their regional context. If one may call the shift from a linear model of innovation towards an interactive one a shift in paradigm, then the main goal of SMEPOL is to provide evidence for a similar shift towards a new innovation policy paradigm. The aim of this paper is to bring to light the main elements of such a new policy paradigm.

The points of departure of this policy-oriented study are that innovation is a good thing (both on the regional and firm levels) and that there is a call for public intervention 
in order to get more of it. As a background, based on the literature, the theoretical part of the study builds on these basic assumptions, which includes two main arguments.

First, the study argues that SMEs are an important target group for innovation policy. ${ }^{5}$ It provides three distinctive characteristics of SMEs, which form the basis for arguments and implications for innovation policy addressed to SMEs. These distinctive characteristics (compared to larger firms) are: a limited resource base, a distinctive organizational culture linked to the proximity between ownership and management, and a lower ability to shape their external environment. These characteristics, which call for distinctive policy approaches, are at the roots of the more informal, uncodified character of management and innovation practices in SMEs. According to this view, the thrust of policy approaches should be two-fold: to increase the availability of external resources for SMEs and to develop their internal absorptive and learning capacities. ${ }^{6}$ This points to the crucial role of intermediaries who, working on the basis of personal trust relations, are able to codify SMEs' needs; to the value of 'peer' networks as learning channels; and to the key role of human capital in SMEs.

Second, the study asserts the importance of the regional dimension of innovation. The discussion develops the thesis that proximity linkages can be instrumental in developing 'learning firms' and 'learning regions'. Also, broadening and extending the concept of clusters towards one of coalition development, points to a broader scope for innovation policy, that of supporting the social and cultural aspects of innovation and enhancing social capital as a key element behind well-functioning regional innovation systems. Developing collective capacities and networking practices at the local level follows logically from this policy aim, but this goal should also be complemented with support to the development of linkages at national and international levels, in order to avoid being trapped by too strong local ties, possibly leading to lock-in situations.

This paper is organized as follows. Based on the findings achieved in this comparative research, Sections 1 and 2 lay the claim for a new innovation policy paradigm and propose a shift in rationale (Section 1) and in the broad orientations (Section 2) of innovation policy to addressing SMEs in their regional context. These arguments are based on the notions of market failures and system deficits, which show up as barriers to innovation processes in regions and SMEs, and on what we may call government failures, shown by the evaluation of instruments. The key argument of this paper is synthesized in Section 3, where a stylized view on the content of a sound regional innovation policy for SMEs is presented. Section 4 deals with the question of how to build a coherent portfolio of policy instruments, taking into account both regional situations and specific SMEs needs in terms of innovation. The key message delivered is that there is no 'onesize-fits-all' policy portfolio. The concluding section draws the lessons from the whole exercise of evaluating, in a comparative fashion, a variety of policy tools, within a common conceptual framework. One salient element of the conclusion is the need for more 'policy intelligence' in this complex field.

\section{The Rationale for Policy Intervention: Failures, Barriers and Boundaries}

Whether we talk about markets, systems or governments in relation to innovation, it all concerns communication, a process of exchanging information and knowledge. In order to be useful and valuable to others in a firm, market, system or government administration, technological (and other) knowledge has to be diffused and policy lessons have to be learned. 
The typical and traditional approach to communication in economics focuses on markets where price mediates supply and demand, whereas, the 'neoclassical' government typically communicates power based on a hierarchical position vis-à-vis the economic agents they govern. In accordance with traditional market-hierarchy dichotomies, the typical argument for government intervention is when markets fail in communication. Either the market or the government would provide the best solution. In general, interactive communication is not considered to be of vital importance in the process of finding and reaching solutions. This linear perspective prevailed even before it had been applied to innovation.

When everybody knows in advance what (products, resources, technologies, capabilities, etc.) are being talked about and everybody would agree on its (present and future) economic value, the market is perfectly able to communicate supply and demand. In these situations there is no need for interactive communication. Whether it is the 'demander' or the 'supplier' who names the price, the market will, in a linear response, come up with the proper answer. For the exchange of certain goods or services, the price may be the only aspect that has to be communicated. However, when knowledge or innovation is concerned, the price mechanism may not function very well.

Following the same logic for policy decision-making, a central question for a policymaker is: how do I recognize where and when markets fail, so that I know where and when to intervene? If it is perfectly clear to policy makers where markets fail, and it is widely agreed upon what the governed region additionally 'needs' and 'has to offer' (more specifically, what firms 'need' from their region, including government, and what they have to offer their region and its policy goals), then there is no need for interaction. Everything is clear: there is no knowledge left to be codified, there is only information to be passed on. Since interaction is costly in terms of time and energy, linear and topdown communication is likely to be more efficient.

However, to deal with the uncertainties attached to knowledge and innovation, ${ }^{7}$ economic and policy agents may want to communicate more than price or authority. The traditional concept of markets and (state) hierarchies with their anonymous, linear and formal communication, fails to incorporate these broader information needs. A reason why markets as co-ordination and communication mechanisms may not function very well regarding innovation is related to the uncertainties attached to predicting the future. ${ }^{8}$ The market may fail to predict the economic value of new technologies, new products, new resources, new firms or new entrepreneurial capabilities. Typically, the market will, for instance, not be able to value a start-up firm. Although policy makers also have difficulties in predicting the future, this kind of market failure is a widely accepted justification for public intervention. For example, a generic national policy tool, like a tax-reduction scheme, seems relevant to 'protect' these young, new entrepreneurial experiments, providing them a chance to prove themselves and to convince the market (that is, customers, but also financial and labour markets) of their potential and, moreover, to convince the government of their potential contribution to the region and its policy goals. The same arguments may hold for new sectors or technologies or a young regional cluster of firms, or even older non-innovative firms that want to and are trying to become innovative.

Another place where markets obviously fail is in communicating certain environmental and social costs and benefits. If economic agents do not take these types of 'costs' into account, governments may want to intervene and extend the boundaries of the rationality of the agents they govern, e.g. by influencing their cost-benefit calculations with environmental taxes.

The justification for traditional technology or R\&D policy has been put forth by 
Arrow, and is based on the macro-level argument that when social effects are taken into account, there is under-investment in $\mathrm{R} \& \mathrm{D}$. The risk and uncertainty attached to $\mathrm{R} \& \mathrm{D}$ by private actors calls for public intervention because, at the macro-level, it is considered worthwhile to publicly take the risk for the sake of society, e.g. by financing public R\&D in universities or, again, by influencing private, micro-level cost-benefit calculations with tax-deduction subsidized facilities.

The idea that there is a role for policy makers, if markets fail, does not imply that policy makers are perfect, but that the above-mentioned general or structural market failures may very well be effectively and efficiently addressed by generic policy instruments, designed and delivered at the national policy level. Further, to diffuse information on needs and support, linear communication seems appropriate. However, knowledge differs from information. For instance, distance does not seem to be a barrier to the transmission of information, but in the transmission of knowledge it does.

The importance of the tacit dimension, ${ }^{9}$ the informal, uncodified and disembodied aspects of the knowledge concerned, both at the regional level and for SMEs, underscores the localized nature of knowledge spill-overs. ${ }^{10}$ The linear communication arguments using the old market-hierarchy approaches fail to address this. Proximity matters to knowledge spill-overs and interaction between regional agents (both private and public) matters in dealing with the uncertainties attached to innovation processes in regions and SMEs. The variety of situations regarding innovation, SMEs and regions calls for communicative interaction. ${ }^{11}$ Local discussions, private and public-private ones, can shed more light on the uncertainty issues. Exchanging tacit visions, converging ideas and coordinating investments decisions (public, private and public/private ones) may provide the knowledge base for an innovation strategy concerning SMEs and their regions. ${ }^{12}$

Especially concerning innovation processes in regions and SMEs, the concept of systems (or networks or clusters) seems a more realistic model to follow than the traditional concepts of markets and hierarchies. ${ }^{13}$ A regional innovation system approach stresses the importance of the diffusion of knowledge and interactive learning within the region as a system. ${ }^{14}$ The non-anonymous relations, the complementarity of activities and the historical setting are stressed in specifying the regional context and the profile of the region's SMEs. These give the regional system its identity, so to speak. ${ }^{15}$ Further, in order to find out and articulate what a particular region or firm needs, or what is lacking concerning innovation, regional proximity and communicative interaction may be needed to address the tacit and latent aspects of such needs. ${ }^{16}$ Providing R\&D tax reduction or subsidies may not be enough to change the rationality (nor its boundaries) of SMEs regarding innovation processes.

\section{Lessons from Evaluating 40 Innovation Policy Tools in 10 European Regions}

Having discussed the rationale for policy intervention in innovation, this section deals with the content of such policies, proposing general principles for their design and implementation (Section 2.1) and observing how these principles match with practice in the case study regions (Section 2.2).

\subsection{Basic Principles for Innovation Support Policies}

Building on the conceptual and empirical findings of the SMEPOL project, the analysis puts forth the following proposition: 
Since the main distinguishing features of the majority of SMEs, with regard to the innovation process, are that: they have a limited resource base, they need external orientation to understand and (proactively) adapt to their environment, and they engage in innovation on an informal mode; the main role for innovation policy, which aims to increase the capacity of a region and the capabilities of its SMEs to innovate, is to foster interactive learning within the firms and within the region. This calls for an interactive mode of policy intervention.

Of course, this statement stands as a quite bold generalization of both the SME's characteristics and policy challenges. Some SMEs have a quite advanced knowledge base (e.g. new technology-based firms), others have developed excellent innovation management capabilities and explicit innovation strategies, and some firms in niches really shape their business environment rather than being dependent on it. Also, there are problems of another nature that keep SMEs from innovating, such as the need for risk financing ${ }^{17}$ or the necessity to access state-of-the-art technology. However, the meaning of this proposal is to point to the orientation of policies needed to address the key needs of the majority of SMEs in most regions, which are not properly taken into account in traditional policy approaches. This does not imply that linear approaches and tools are not relevant anymore, but rather, it puts the latter in perspective. It means that providing resources to innovate (finance, technology) is not sufficient if the firms do not possess the managerial and organizational abilities to deal with the innovative process. ${ }^{18}$ The view of an 'automatic' flow of technological resources through the firm, or from the R\&D sector into the firm, is argued against here, while increased attention is given to the innovation process (within and around the firm) itself, in a broader sense.

Nevertheless, fostering interactive learning, as a policy goal, should not be read in a dogmatic egalitarian sense, limiting the view to the development of 'Third-Italy' type of horizontal networking and relationships as an ideal way to foster that process. Hierarchical relationships might be very relevant ways to achieve such an objective too, depending on the environment. As developed in Section 1, the role of geographical proximity might be important to nurture learning relationships, but it is not a necessary ingredient everywhere. The point here is that being open to outside sources of knowledge and having the capacity to integrate these with internal knowledge in the firm in a continuous mode, is key to the innovation process. Such an objective has implications both on the supply-side (outside resources should exist, be organized and accessible to firms) and on the demand side (the firm's absorption capacity and its willingness to entertain links with the outside should be enhanced). Developing strategic capabilities, at the firm, organization and policy levels, lies at the heart of this challenge.

The idea of an interactive mode of policy implementation means not only that services should be both designed and delivered in co-operation with the beneficiaries, but also, that the policy implementers can be partners in the supported action or project, so that learning can happen both ways - between policy implementers and firmsreferred to as 'communicative interaction' in Section 1 above. In this approach, the tacit nature of innovation in SMEs is better addressed than in more hierarchical policy modes.

\subsection{Application of the Basic Principles}

If the proposition above is the theoretical challenge for policy, how does it compare with practice, as experienced in the regions covered by the SMEPOL study?

A horizontal overview and comparison of the analyses of forty policy tools in eleven European regions, shows that such a challenge is hardly met by the policies at work in 
these regions. Both the content and the modes of delivery of policies are in most cases not interactive and fit better with a market-hierarchy than a system approach.

More precisely, the SMEPOL analyses deliver the following picture:

(1) The general situation is that linear tools are dominating the policy scene, but that everywhere an evolution towards more interactive support is visible.

(2) A set of policy instruments, in general, does not form a system: lack of co-ordination and of synergies among tools at work in one region is the rule.

(3) Few policy instruments are designed and implemented in an user-oriented mode, taking both expressed and latent needs of users into account: the majority of tools are developed in a reactive, top-down fashion and at best consider expressed (but not latent) firms' needs. However, in cases where 'voice' of users (i.e. firms' expressed, or even latent, needs) is taken into account, the tools become much more useroriented.

(4) Policy learning is still rare and underdeveloped. If it occurs at the level of organizations, it takes place in an occasional, non-routine way. Intense policy learning practices may, however, result in undesirable volatility in the policy system. At the other extreme, it seems unjustified to maintain a range of tools that are virtually not used by firms. The challenge lies in fine-tuning the policy tools without letting firms suffer from the instability of the system.

(5) There is an emerging new tendency of developing 'overall schemes', gathering into a single programme, instrument, or organization, a set of tools that traditionally are proposed separately to companies. This approach is promising in that it fits well with the global perception of innovation within firms: it impinges on all activities of the firm.

(6) The majority of instruments aim at improving or facilitating existing innovation projects, rather than inducing new innovation practices. Providing grants for R\&D, for example, seems to induce a rather small incremental behavioural effect (in terms of changing strategy, management or culture regarding innovation, co-operation and interactive learning). Therefore, the value-added of such policy instruments is questionable.

(7) The question of penetration rate of the tools in the business sector is not always addressed in policy settings. For example, where a 'picking-the-winner' approach is taken, a focus on the visibility of results may act detrimentally to the value-addedness of the scheme.

(8) Very often, tools designed at a regional level work under a closed vision of the relevant sources of knowledge useful for firms, because the boundaries of the system are defined in administrative terms. If tools could be more user-oriented, there would be no need for such a restricted view.

(9) Overall, there is a decrease in attention on the available policy support for the five following innovation support needs reported by SMEs:

- Finance/risk sharing

- Technology/technical know-how

- Qualifications/personnel

- Market access/information

- Time constraints/organization/strategic capabilities.

The lack of 'market orientation' of the policy tools, or their lack of focus on the commercialization aspects of innovation, is particularly evident. 


\section{A Synthesis Policy Directed at Innovation in SMEs in a Regional Context}

The SMEPOL study has revealed a high degree of heterogeneity in policy instruments aiming at fostering innovation in SMEs. The instruments have various goals, such as, for instance, linking SMEs with R\&D producing institutions or strengthening human resources within companies. The support also comes in various forms, like direct financial support, or services from technological centres or brokers, or under the name of cluster policy. Some policies clearly have a national origin while others may be classified as regional. Moreover, and perhaps of more fundamental importance, the policy instruments touch on different points of intervention in individual firms' innovation processes, or even different phases of the (collective) innovation path of the regional system these firms may belong to. For instance, the abilities and attitudes vis-à-vis innovation of firms targeted by awareness raising instruments differ from the abilities and attitudes addressed by 'linear' instruments. Some tools might help to create the necessary awareness and capabilities in firms, so they can afterwards be supported with more standardized schemes when they have moved further up their learning curve. A proper sequence of instruments is then more appropriate than a search for universally and permanently adequate tools.

The diversity evidenced is not, of course, a surprise considering the variety among SMEs, their regional contexts and most of all the innovation processes. Notwithstanding this multi-layered diversity, we can construct a simple two-dimensional classification of the policy instruments, which presents a synthesized view along two key issues concerning a shift or change in policy paradigm (see Table 1). We have classified the SMEPOL instruments according to the two following key fundamental characteristics:

- Target level of support: firm-oriented or (regional) system-oriented.

With the term 'system', we explicitly refer to regional systems. This does not imply that national or global systems or networks are irrelevant bases for economic co-ordination, but it expresses the claimed importance of the regional environment for innovation in SMEs. Some tools focus on innovation and learning within firms while others focus on crossing firm boundaries, aiming for externalities or synergies stemming from complementarity within the region as an innovation system. The logic behind (regional) systemoriented support is based on the idea that the innovation capacity and performance of a regional system may be larger than the 'sum' of the internal innovation capacity and performance of the individual 'members' of the system.

- Form and focus of support: focused on allocation of resources as inputs for innovation or focused on learning aiming for behavioural value-added.

At one extreme the policy approach is to raise the endowment, the stock of given resources (in firms and regions) as inputs for innovation. In a reactive mode of intervention, the policy instruments aim at increasing innovation capacity by making the necessary resource inputs available. The principal idea in the latter approach is that the window of opportunities and problems towards innovation and support are clear and that, given the lack (and need) of certain resource-inputs, policy makers increase the innovation output by allocating resources, that is, providing the innovation inputs or increasing their availability (again internally within the firm or externally, within the region). At the other extreme are the instruments that focus on learning, trying to act on behavioural aspects like the organizational culture, innovation strategy, management, mentality, or the level of awareness. They focus on creating or changing the windows of opportunities and problems concerning innovation and innovation policies. Accordingly, the mode of intervention is a proactive and interactive one. The principal idea is that the involved 
Table 1. Classification of policy instruments studied in SMEPOL

Form and focus of innovation support

\begin{tabular}{|c|c|c|}
\hline $\begin{array}{l}\text { Target level } \\
\text { of support }\end{array}$ & $\begin{array}{l}\text { Input resources } \\
\text { (reactive tools allocating inputs for innovation) }\end{array}$ & $\begin{array}{l}\text { Behavioural value added } \\
\text { (proactive tools focusing on learning to innovate) }\end{array}$ \\
\hline ted & \begin{tabular}{l}
\multicolumn{1}{c}{$\mathbf{A}$} \\
- Traditional firms' R\&D subsidies \& loans \\
- Risk capital \\
- Training subsidies \\
- Incubators with 'hard' support \\
- Research centres \\
- Traditional 'reactive' technology centres \\
- Transfer units in universities
\end{tabular} & $\begin{array}{l}\text { B } \\
\text { - Subsidy for hiring innovation managers in } \\
\text { SMEs } \\
\text { - Loans for competence development } \\
\text { - Management advice } \\
\text { - Incubators with 'soft' support } \\
\text { - Business Innovation Centres } \\
\text { - 'Pro-active' technology centres } \\
\text { - Audits, monitoring needs } \\
\text { - Innovation coach } \\
\text { - Innovation management training and advice }\end{array}$ \\
\hline (Regional) & $\mathbf{C}$ & D \\
\hline $\begin{array}{l}\text { System- } \\
\text { oriented }\end{array}$ & $\begin{array}{l}\text { - Mobility schemes research-industry } \\
\text { - Co-operative schemes HEI-industry } \\
\text { - Subsidy for co-operative R\&D projects } \\
\text { - Subsidy to promote use of business services } \\
\text { - Collective, user-oriented technology or } \\
\text { innovation centres }\end{array}$ & $\begin{array}{l}\text { - Proactive brokers, match-makers } \\
\text { - Cluster policies } \\
\text { - Support for firm-networking } \\
\text { - Umbrella schemes } \\
\text { - Local strategic plans } \\
\text { - Schemes acting on the culture of innovation } \\
\text { - RTP and RIS/RITTS kind of programmes } \\
\text { (fostering strategic capabilities of policy } \\
\text { makers) }\end{array}$ \\
\hline
\end{tabular}

agents (private and public, individually or collectively) learn by doing, by using and by interacting. During innovation, using resources and interacting with others improves the awareness, the behavioural routines and the rationality towards innovation (and innovation policy).

Each of the four quadrants of Table 1 can be traced back to its own theoretical background or tradition ranging from atomistic to holistic approaches, and solutions from neoclassical and evolutionary traditions. The typology incorporates them all and, in fact, it is suggested that in practice none of them is irrelevant in aiming for a change in innovative performance. 'Linear' tools directly aim for more innovation performance, while 'interactive' tools address innovation behaviour, but addressing behaviour is only meaningful if, in the end, it results in better performance.

Every policy in principle aims at changing behaviour. Policy makers can affect the innovative behaviour of firms directly via subsidies and individual projects or indirectly via the provision of 'hard' or 'soft' public infrastructure and institutions like universities or technology centres. In a neoclassical reasoning, providing subsidies as an input to the innovation process is an intervention method to affect the innovative behaviour of firms directly by influencing the choices based on the cost/benefit calculations of the agents. An input-subsidy for R\&D or for hiring an expensive highly educated employee for instance affects the decisions regarding resource allocation immediately.

A more evolutionary approach to policy incorporates learning. In this respect subsidies for R\&D can provide a learning experience. Within a 'learning-to-innovate' framework, policy support can get an innovation process started and support a change in the innovative behaviour in firms or regions. The support may also result in the static effect of more innovation output, but more importantly it aims for dynamic effects, effects that 
go on after the support stops. The argument for policy then becomes temporal. Timing and the ex-ante conditions become important. The reasoning behind policy becomes more proactive than reactive. The difficulty with reactive policy is to know exactly what is required either by the firm or the region. Some expressed needs may be 'over-supported' while others may be latent, neglected, tacit and not supported. The articulation of the need then has to become part of the policy process, albeit in an interactive way. Merely providing the resource inputs that the policymakers think are relevant may not be enough to induce a real change in future behaviour.

Two instruments studied in the SMEPOL project provide an example of the difference between reactive and proactive tools. Similar at first sight, the two instruments serve different purposes, because one is more reactive and the other more proactive. Both the RIT scheme in Wallonia and the KIM scheme in Dutch Limburg are subsidies in order to hire personnel for SMEs in order to work on innovation projects, with the objective to target firms that are not already innovative. In the Walloon case, the firm itself had to write a formal technological development project and submit the proposal to the administration, which decided on the subsidy according to the quality of the proposal and the results of an audit in the firm. The person employed needed to be a technician. In the Limburg case, an intermediary (Syntens, the innovation centre), helped the firm identify when such a scheme would be useful, helped to find the candidate as needed, and did not require a formal project as a condition for the allocation of the subsidy. The types of personnel employed were not restricted to people possessing technological competences, but could also cover commercial or managerial weaknesses in the firm. It was clear that the RIT mainly responds to the financial need of the company. Many SMEs do not use the RIT, because the formal requirement to codify a technological development project constitutes a barrier, and also because other financial sources are more easily accessible. In the case of KIM, the focus was more on the change of behaviour of the firm and there was an interaction between the firm and the support provider, within a more open view on the innovation project.

Table 1 can be used to examine under which paradigm issues (neoclassical or more evolutionary) the 40 SMEPOL policy instruments are developed and implemented.

The A type of instruments may be classified as more 'traditional' while D type of instruments seem more 'innovative', but this does not mean that instruments in one of the four quadrants are intrinsically better than instruments in any of the other quadrants. There are still sound arguments for each and every type of tool. The question turns more into one of the choice of the appropriate policy portfolio, anticipating the needs of the region (see Section 4 below). Concerning the resource oriented tools $\mathrm{A}$ and $\mathrm{C}$, the national policy level may in many cases be more relevant than the regional policy level, especially if the support is needed at firm level and the lack of (internal or external) resources for innovation is not region-specific.

The relevance of A-, B-, C- as well as D-types of tools not only relates to different regional conditions, such as the intensity of existing co-operation practices, for instance, but also it relates to the various identified distinctive characteristics of SMEs. The sizerelated characteristics affect the needs for support as well as the way the support can be delivered effectively. SMEs' limited resource base, for instance, finds a response in A- or C-type tools. The A-type focuses on raising endowment within firms and the C-type tools on raising endowments of the innovation system of which the SME is part, or is 'invited' to be a part. SMEs' distinctive organizational culture and management practices receive a better response in B-type tools, which try to influence certain attitudinal and behavioural aspects within the SMEs. The lesser ability of SMEs to shape their environment, compared to larger firms, might be addressed by D-type tools. These tools have to tackle 
the external uncertainties that smaller firms are typically faced with by enhancing the capacity of the firm to understand its environment and to become part of it (e.g. by forming clusters). That is, to become pro- and interactive members of a regional innovation system rather than staying passive, unaware and incapable of adapting or influencing others towards adoption. This calls for external awareness and tools that teach SMEs how to identify, value, use and develop regional resources and interact with resource-owners.

The correspondence between the distinctive characteristics of SMEs regarding innovation and the various policy approaches shows, first of all, that each of the four types of policy instruments is relevant and, second, that the instruments have to be designed to address SMEs' needs, expressed as well as latent ones.

The main outcome of the SMEPOL study is that the policy tools are too concentrated in category A (e.g. in the form of firms' subsidies), and that there are few instruments in category D (e.g. support for cluster forming). All types of instruments are relevant to different types of firms and different types of environments (and at different points in time), but the main gaps in the support systems in the SMEPOL cases, are found in category D. In order to conduct a change in perspective, it seems necessary, however, in most cases to first develop instruments of the B and C types, before the system and agents are ready to implement and absorb D-type instruments.

As stated before, in any specific regional situation, there will probably be a need for a mix of A-, B-, C- and D-types of instruments. For example, A- and C-type instruments will still be particularly relevant for new technology-based firms and spin-offs. B-type instruments could be used for less innovation-aware firms. Building internal capability is a necessary step in most cases before being able to participate in a D-type instrument interaction with other innovating agents.

If a region does not have a lot of innovative SMEs, providing ever-more resources to the same group of firms seems less appropriate than extending the number of innovators by approaching non-innovating SMEs with B-type tools. Enhancing a firm's learning process and preparing them for more interactive behaviour can subsequently be supported by C- or D-type tools. If there is no lack of innovators but they seem to innovate in relative isolation, C-type tools might create more openness and stimulate the use of external resources in the region.

There are also arguments to develop linkages between tools of the various categories. In general, however, the proactive provision of internal and external learning experience with B- and D-type instruments respectively, will create new clients and new resource needs, which may subsequently be effectively addressed with the reactive provision of internal or external resources. The other logical sequential link refers to the fact that a certain level of internal resources and learning experiences are needed before systemoriented tools can be effective. This calls for the need of excellent co-ordination and the development of synergies between all tools at work in the environment.

This discussion also links with the question of the relevance of different levels of authorities for the various policy activities like design, adaptation, learning, implementation and evaluation. Proactive tools imply more freedom of action and closeness to beneficiaries, more likely to be found at regional level, while reactive, standard tools are more adapted to higher levels of authorities.

\section{Gustomizing a Policy Portfolio to Regional Specificities}

Regional differences in innovation capabilities call for a tailored mix of policy instruments. This section, therefore, reflects on the question of the appropriate policy portfolio to be 
Table 2. Policy responses to regions' and SMEs' problems with innovation: an illustration of possible policy objectives and tools

\begin{tabular}{|c|c|c|c|}
\hline \multirow[b]{2}{*}{ SMEs' needs } & \multicolumn{3}{|c|}{ Regional innovation system problems } \\
\hline & Organizational thinness & Fragmentation & Lock-in \\
\hline \multirow[t]{2}{*}{ Financial } & $\begin{array}{l}\text { Attract and retain innovating } \\
\text { firms }\end{array}$ & $\begin{array}{l}\text { Coach firms in linking to } \\
\text { finance sources }\end{array}$ & $\begin{array}{l}\text { Ensure long term finance for } \\
\text { 'overall' innovation project }\end{array}$ \\
\hline & $\begin{array}{l}\text { Foster firms to go global, link } \\
\text { them to international partners } \\
\text { and external financial } \\
\text { resources }\end{array}$ & $\begin{array}{l}\text { Foster specialization by } \\
\text { combining technological } \\
\text { support and finance } \\
\text { Support the formation of } \\
\text { sector-specific Venture capital } \\
\text { funds }\end{array}$ & $\begin{array}{l}\text { Support new firm creation } \\
\text { Address succession problems } \\
\text { Restructure mature industries } \\
\text { by attracting FDI and } \\
\text { promoting international } \\
\text { partnerships }\end{array}$ \\
\hline Technological & $\begin{array}{l}\text { Link firms with technological } \\
\text { resources outside the region } \\
\text { Promote collective sourcing } \\
\text { and investments in collective } \\
\text { resources, technology centres } \\
\text { Use private R\&D centres as } \\
\text { technology resources for other } \\
\text { firms }\end{array}$ & $\begin{array}{l}\text { Provide bridge between firms } \\
\text { and technological resources, } \\
\text { brokers } \\
\text { Provide 'accessible' technology: } \\
\text { co-operative schemes HEI- } \\
\text { SMEs } \\
\text { Finance firms to access } \\
\text { technology centres }\end{array}$ & $\begin{array}{l}\text { Push firms to seek for new } \\
\text { technology options } \\
\text { Foster access to resources } \\
\text { outside the region, } \\
\text { international partnerships } \\
\text { Restructure the technology } \\
\text { support infrastructure towards } \\
\text { new technologies and sectors }\end{array}$ \\
\hline $\begin{array}{l}\text { Human } \\
\text { resources }\end{array}$ & $\begin{array}{l}\text { Attract/retain highly skilled } \\
\text { workers }\end{array}$ & $\begin{array}{l}\text { Foster exchange of codified } \\
\text { and tacit knowledge }\end{array}$ & $\begin{array}{l}\text { Develop creative capacities of } \\
\text { workers }\end{array}$ \\
\hline & $\begin{array}{l}\text { Support collective training } \\
\text { programmes }\end{array}$ & $\begin{array}{l}\text { Foster intra-firm nodes for co- } \\
\text { operation: hiring of researchers } \\
\text { in SMEs }\end{array}$ & $\begin{array}{l}\text { Subsidy to hire personnel for } \\
\text { innovation }\end{array}$ \\
\hline $\begin{array}{l}\text { Openness } \\
\text { and learning } \\
\text { attitude }\end{array}$ & $\begin{array}{l}\text { Promotion of networking } \\
\text { between firms, and clusters at } \\
\text { every geographical scale }\end{array}$ & $\begin{array}{l}\text { Foster a more collaborative } \\
\text { spirit and more strategic } \\
\text { orientation in the regions, } \\
\text { Regional Development } \\
\text { Agencies } \\
\text { Combine funding with } \\
\text { interaction stimulation, } \\
\text { Umbrella schemes }\end{array}$ & $\begin{array}{l}\text { Help SMEs evolve towards } \\
\text { more creativity and autonomy } \\
\text { in production, supply-chain } \\
\text { learning, demonstration } \\
\text { projects }\end{array}$ \\
\hline $\begin{array}{l}\text { Strategy and } \\
\text { organization }\end{array}$ & $\begin{array}{l}\text { Support firms in linking to } \\
\text { international input and output } \\
\text { markets } \\
\text { Develop systemic character of } \\
\text { innovation support: network } \\
\text { brokers }\end{array}$ & $\begin{array}{l}\text { Help firms identify, articulate } \\
\text { and 'de-bundling' their needs: } \\
\text { Innovation coach } \\
\text { Invite firms collectively to help } \\
\text { in formulating a regional } \\
\text { innovation strategy: } \\
\text { RIS/RITTS }\end{array}$ & $\begin{array}{l}\text { Open windows of } \\
\text { opportunities for SMEs: } \\
\text { techno-economic intelligence } \\
\text { schemes, innovation } \\
\text { management training }\end{array}$ \\
\hline
\end{tabular}

developed in a regional context. For targeting of policy, characteristics of the region as a whole and SME-specific challenges for innovation are taken as the point of departure. To achieve the objective of identification of policy portfolios, Table 2 proposes a picture of the situation, which combines the results of the analyses gathered in the SMEPOL study, i.e. the analysis of the main potential strengths and deficits of regional innovation systems and the analysis of the main firms incentives and barriers with regard to innovation. The combination of regional and firm's characteristics should form the basis for the design of policy intervention. 
The aim of Table 2 is to enlighten possible policy responses to certain innovation barriers, deficits or challenges at regional and firm level. Each cell of this table contains two elements: the policy tool's objectives and an example of an appropriate instrument.

Such a table shows clearly that there is no 'one-size-fits-all' policy system: it depends on the problems and opportunities to be addressed in the existing context. It also shows the need for policy to provide longer term and holistic support to innovation in all its aspects. But it is nevertheless possible to develop recommendations per category of firms' problems (horizontal lines in the table), per regional context (vertical lines in the table) and per type of policy tool (within each cell, every tool can be benchmarked against the broad guidelines for policy and against similar tools of the same type).

In light of such a table of possible instruments, it becomes clear that the main role of the policy maker becomes setting priorities according to the perceived potential and problems in the region, to align with the main orientation of the economic development policy of the region.

The main condition however for the usefulness of the proposed approach, as a guide to re-designing innovation policies targeting SMEs, is that on the policy side also, learning processes are at stake and adequate strategic capabilities are present. In trying to create learning firms within learning regions there is a need for learning governments.

In particular this implies:

(1) That the regional situation, that is, the particular needs and opportunities (for innovation support) of SMEs and the regional innovation system as a whole, are well mapped, communicated and understood by policy designers;

(2) That the objectives set for policy instruments are clearly expressed ex-ante in a global coherent framework and that the expected results are measurable;

(3) That the results and impacts of the instruments are monitored properly and then evaluated by an independent third party, in combination with peers' and clients' views;

(4) That lessons from the evaluation are acknowledged and diffused, and that they are confronted with the policy aims, in order to adjust the policy approach in a continuous manner and its instruments accordingly.

In most of the regions studied in SMEPOL, deficiencies have been noted in all the aspects listed above: a detailed knowledge of the specifics of the regional innovation system is often absent, not properly diffused in a language understandable by policy makers, or updated with sufficient regularity; effects of policies are often measured in a 'funds consumption' approach only; evaluation is not built in the design of the programmes; no real independent evaluation of results and impacts are undertaken in most cases; pilot, bottom-up experiments are not really assessed and there is thus a failure to capture lessons from these experiments; and policy learning is, in general, underdeveloped.

\section{Conclusion}

Drawing on the SMEPOL findings we have questioned in this paper how policy directed at innovation in SMEs can be improved. After discussing several rationales for policy, we came up with a main question, that is, did we witness an actual shift in the policy paradigm or did we find arguments that call for a new policy paradigm? Our conclusion is that we have witnessed some shifts in practice and that we have found sound arguments that support our claim that a shift in rationale is needed to improve the policy directed at innovation in SMEs.

More precisely, we used Table 1 in Section 3 to discuss the way to combine tools that 
are reactive or proactive and target internal processes in SMEs and tools that are proactive and target the externalization of SMEs or the functioning of the regional innovation system.

We also proposed a reflection on policy mixes in Section 4, using Table 2, showing clearly that similar SME problems need to be tackled differently according to the regional context, but also that there is scope for importing elements of good practices from one context into another.

With this discussion, we can conclude that such an analysis, with the three key features of:

- Matching the context and SME needs' pictures with the policy tools in each region;

- Confronting the policy tools with the lessons of theory;

- Comparing results achieved with a range of policy instruments in different environments, is suitable for improving SME innovation support policies in the EU regions.

The best way to evolve in such a direction, however, would be to undertake such a strategic benchmarking exercise with the active participation of policy makers and policy implementers themselves. Theoretically sensible ideas could then be confronted with reality.

\section{Notes and References}

1. R. Rothwell, 'Successful Industrial Innovation: Critical Factors for the 1990s', RङD Management, 22, 1992, pp. 221-237.

2. L. Soete \& A. Arundel, An Integrated Approach to European Innovation and Technology Diffusion Policy: A Maastricht Memorandum, Publication No. EUR15090, European Commission, Luxembourg, 1993; R. Cowan \& G. van de Paal, Innovation Policy in a Knowledge-based Economy, Publication No. EUR17023, European Commission, Luxembourg, 2000.

3. University of Economics and Business Administration, Austria; Centre for Small Business Studies, Denmark; Universitá degli Studi di Pavia, Italy; Maastricht Economic Research Institute on Innovation and Technology, The Netherlands; The STEP Group, Norway (project co-ordinator); Universidad Autonoma de Madrid, Spain; and Middlesex University, The United Kingdom. See A. Kaufmann \& F. Tödtling, Innovation Support for SMEs in Upper Austria. SMEPOL Report No. 1, Vienna, 1999; A. Kaufmann \& F. Tödtling, Innovation Patterns of SMEs. SMEPOL Final Report, Vienna, 1999; P.R. Christensen, A. Cornett \& K. Philipsen, Innovations \& Innovation Support for SMEs - The Triangle Region of Denmark. SMEPOL Report No. 2, Kolding, 1999; P.R. Christensen, A. Cornett \& K. Philipsen, Coherence of Innovation Policy Instruments. SMEPOL Final Report, Kolding, 1999; G. Garofoli (Ed.), SMEs, Innovation Trajectories and Policies: The Case of Lombardy and Apulia. SMEPOL Report No. 3, Pavia, 1999; G. Garofoli \& B. Musyck, Overview of Regional Innovation Policy Instruments. SMEPOL Final Report, Pavia, 1999; C. Nauwelaers, N. Schall \& R. Wintjes, SME Policy and the Regional Dimension of Innovation: The Cases of Wallonia and Limburg. SMEPOL Report No. 4, Maastricht, 1999; C. Nauwelaers \& R. Wintjes, Towards a new Paradigm for Innovation Policy? SMEPOL Final Report, Maastricht, 1999; B. Asheim \& A. Isaksen, SMEs and the Regional Dimension of Innovation. The Norwegian Report. SMEPOL Report No. 5, Oslo, 1999; A. Isaksen, B. Asheim, S.O. Remøe (Eds), SME Policy and the Regional Dimension of Innovation. The Norwegian Report. SMEPOL Report No. 5, Oslo, 1999; A. Isaksen, National and Regional Contexts for Innovation. SMEPOL Final Report, Oslo, 1999; A. Vázquez Barquero, J.A. Gil, A. Sáez Cala, A. Viñas Apaolaza \& M. Atienza Úbeda, SME Policy and the Regional Dimension of Innovation: The Spanish Report. SMEPOL Report No. 6, Madrid, 1999; J.A. Gil, A. Sáez Cala, A. Vázquez Barquero, A. Viñas Apaolaza, Results and Impacts of Policy Instruments. SMEPOL Final Report, Madrid, 1999; D. Smallbone, D. North, I. Vickers \& I. McCarthy, SME Policy and the Regional Dimension of Innovation: UK National Report. SMEPOL Report No. 7, Middlesex, 1999; D. Smallbone, D. North \& I. Vickers, SME Policy and 
the Regional Dimension of Innovation: Background: The Role and Characteristics of SMEs. SMEPOL Final Report, Middlesex, 1999.

4. Upper Austria, Wallonia in Belgium, the Triangle region in southern Jutland (Denmark), Lombardy and Apulia in Italy, Limburg in the Netherlands, northern and south-eastern Norway, Valencia in Spain, parts of London (Lee Valley) and parts of its outer metropolitan area (Hertfordshire).

5. These arguments have been developed by the British team in SMEPOL, Smallbone et al., op. cit., Ref. 3, Final Report.

6. W.M. Cohen \& D.A. Levinthal, 'Innovation and Learning: The Two Faces of R\&D', Economic Journal, 99, 1989, pp. 569-596.

7. G. Dosi, 'The Nature of the Innovative Process', in G. Dosi, G. Freeman et al. (Eds), Technical Change and Economic Theory (London, Pinter, 1988).

8. R. Cowan \& D. Foray, 'The Economics of Codification and the Diffusion of Knowledge', Industrial and Corporate Change, 6(3), 1997, pp. 595-622.

9. M. Polanyi, The Tacit Dimension (London, Routledge, 1996).

10. M. Storper, The Regional World: Territorial Development in a Global Economy (New York, The Guilford Press, 1997).

11. K. Morgan \& C. Nauwelaers, Regional Innovation Strategies: The Challenge for Less-Favoured Regions (London, HMSO, 1999).

12. B.-A. Lundvall, 'User-Producer Relationships, National Systems of Innovation and Internationalisation, in D. Foray \& C. Freeman (Eds), Technology and the Wealth of Nations (London, Pinter, 1983).

13. G. Grabher, The Embedded Firm: On the Socio-Economics of Industrial Networks (London, Routledge, 1993).

14. K. Morgan, 'The Learning Region: Institution, Innovation and Regional Renewal', Regional Studies, 31(5), 1996, pp. 491-503.

15. M. Feldman, The Geography of Innovation (Dordrecht, Kluwer, 1994).

16. M. Landabaso, 'The Promotion of Innovation in Regional Policy: Proposals for a Regional Innovation Strategy', Entrepreneurship and Regional Development, No. 9, 1997.

17. Even there, in most cases, the problem is not so much the existence of risk capital funds but the accessibility of these for SMEs engaged in risky, and sometimes weakly formalized projects.

18. J. Cobbenhagen, Managing Innovation at Company Level (Maastricht, University Press, 1999). 